\title{
Increases in intrahepatic CD68 positive cells, MAC387 positive cells, and proinflammatory cytokines (particularly interleukin 18) in chronic hepatitis $\mathrm{C}$ infection
}

\author{
P H McGuinness, D Painter, S Davies, G W McCaughan
}

\begin{abstract}
Background-Upregulation of Th1 associated intrahepatic cytokines in chronic hepatitis $\mathrm{C}$ virus (HCV) infection should lead to a significant non-specific cellular immune response, a prerequisite for viral clearance. However, to date, the role of this non-specific response in $\mathrm{HCV}$ has been understudied.

Aims-To analyse the intrahepatic macrophage activity in chronic $\mathrm{HCV}$ infection by immunostaining and by quantitation of cytokine mRNA.
\end{abstract}

Methods-HCV positive liver tissues (chronic hepatitis, $n=10$; cirrhosis, $n=5$ ) were immunostained for CD68, MAC387, and semiquantitated by polymerase chain reaction for intrahepatic cytokine mRNAs (interferon $\gamma($ IFN $\gamma)$, interleukin $1 \beta$ (IL-

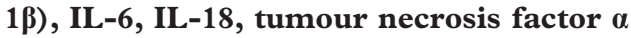
(TNF $\alpha$ ), and macrophage inflammatory protein $1 \beta$ (MIP1ß)). HCV negative normal liver tissues (for cytokines, $n=6$; for immunostaining, $n=5$ ) were included as controls.

Results-MAC $387^{+}$cells were focally increased in areas of erosion at the limiting plate while lobular staining was minimal. $\mathrm{CD}^{+} 8^{+}$staining was diffuse in both portal (increased in HCV) and lobular areas. The portal tract (mean) density of $\mathrm{CD}^{+} 8^{+}$and MAC $387^{+}$cells was significantly increased in patients with HCV compared with normal tissue. IFN $\gamma$ and IL-18 mRNA levels were highly correlated and significantly upregulated in chronic hepatitis and cirrhotic tissue versus controls. TNF $\alpha$ mRNA was upregulated in chronic hepatitis without cirrhosis, while IL-6 mRNA was significantly downregulated. IL-1ß, IL-6, and MIP1 $\beta$ mRNA levels were significantly correlated with portal tract MAC387 $7^{+}$cell density.

Conclusions-The significant upregulation of IFN $\gamma$ and IL-18 mRNA and significant correlations between IFN $\gamma$ and other proinflammatory cytokines, suggest a Th1/cell mediated intrahepatic immune response in chronic HCV infection. However, further clarification of the cellular sources of these cytokines is required. (Gut 2000;46:260-269)

Keywords: hepatitis C; macrophage; cytokine; interleukin; MAC387
It is well established that hepatitis $C$ virus (HCV) infection becomes chronic in greater than $80 \%$ of cases. ${ }^{1-3}$ The reason why $\mathrm{HCV}$ is not cleared from these subjects is not known. Intense research into the complex interaction between viral factors such as genotype, ${ }^{4-6}$ viral load, ${ }^{6-9}$ quasispecies formation, ${ }^{5}{ }^{10}$ high viral turnover, ${ }^{12}$ and host immune factors such as antigen presentation, ${ }^{13} 14$ cell mediated immune response, ${ }^{15-17}$ and the humoral immune responses ${ }^{18-20}$ has yet to reveal any clear reason for chronicity.

Experimental evidence suggests that the immune response to $\mathrm{HCV}$ is site specific (compartmentalised). ${ }^{21-24}$ In this model, the peripheral immune response maybe a $\mathrm{T}$ helper type 2 (Th2) response-that is, HCV induces Th2 cells to proliferate, which in turn triggers a humoral immune response. In contrast, a cell mediated immune $\mathrm{T}$ helper type 1 (Th1) response appears to exist in the liver. ${ }^{15}$ Our laboratory has previously reported a significant intrahepatic upregulation of Th1 associated cytokines (interleukin 2 (IL-2) and interferon $\gamma$ $(\mathrm{IFN} \gamma)$ ) and a significant downregulation of the Th2 cytokine IL-10. ${ }^{23}$ Dumoulin et al likewise found that intrahepatic IL-2 and IFN $\gamma$ mRNA levels were raised in hepatitis $\mathrm{C}$, but they did not find IL-10 mRNA downregulation. ${ }^{16}$

A persistent Th1 response may cause a gradual accumulation of liver injury primarily induced by cytotoxic T lymphocytes (CTLs), natural killer (NK) cells, and macrophages. Although many studies have found evidence that suggests persistent intrahepatic anti-HCV CTL activity in chronic HCV, only a few reports (mostly abstracts) have investigated intrahepatic macrophage activation. ${ }^{25-33}$ The high expression of IFN $\gamma$ present in $\mathrm{HCV}$ infected livers should activate both infiltrating monocytes/macrophages and resident macrophages (Kupffer cells). ${ }^{34}$ These macrophages should then express a range of cytokines such as tumour necrosis factor $\alpha(\mathrm{TNF} \alpha)$, tumour growth factor $\beta$ (TGF $\beta$ ), IL-1 $\beta$, IL-6, IL-10, IL-12, IL-18, and chemokines such as macrophage inflammatory proteins (MIP), which would strengthen the continuation of a $\mathrm{T} 1$ response within the liver and further encourage

Abbreviations used in this paper: DB-PCR, dot blot PCR; CTL, cytotoxic T lymphocyte; HCV, hepatitis $\mathrm{C}$ virus; IFN, interferon; IL, interleukin; MIP, macrophage inflammatory protein; NK, natural killer cell; PCR, polymerase chain reaction; TGF, tumour growth factor; TNF, tumour necrosis factor. 
the migration of macrophages/monocytes and $\mathrm{T}$ cells to the inflammatory site. Also, activated intrahepatic macrophages may take on a cytotoxic profile and destroy infected hepatocytes directly. ${ }^{35}$

Unfortunately, data on intrahepatic macrophage activity in HCV infection are sparse and contradictory. Two studies have detected the upregulation of CD14 expression on macrophages (marker of macrophage activation) in active hepatitis. ${ }^{32} 3536$ This upregulation was shown to be directly related to the degree of liver injury. ${ }^{33}$ In addition, an increase in CD68 (universal marker for monocyte/macrophage lineage $\mathrm{e}^{35}$ ) positive macrophage density has been found to be associated with increased liver damage in $\mathrm{HCV}$ infection. ${ }^{28}{ }^{35}$ In contrast, a study by Marrogi and colleagues ${ }^{28}$ failed to find any association between another macrophage marker, MAC387 (marker for a subset of reactive/infiltrating monocytes/macrophages, ${ }^{37-39}$ but not Kupffer cells ${ }^{37}$ 40-43 ) and $\mathrm{HCV}$ associated liver injury.

Evidence from two studies on intrahepatic macrophage cytokine levels ${ }^{26}{ }^{27}$ found reduced expression of IL-1 $\beta$, IL-6, and TNF $\alpha$ in chronic HCV, which would appear to be inconsistent with macrophage activation. Similarly, a study by Khakoo et al found no significant difference between two different macrophage subsets (antigen presenting versus phagocytic) when three different stages of disease (mild hepatitis, active hepatitis, and advanced cirrhosis) were compared. ${ }^{25}$

The aim of this study was therefore to investigate macrophage activity within the $\mathrm{HCV}$ infected liver by jointly analysing the macrophage infiltrate and state of macrophage activation (immunostaining for macrophage markers and measuring the intrahepatic mRNA expression of cytokines associated with macrophage activation, including the chemokine MIP1 $\beta$ and the recently recognised interferon inducing factor IL-18).

\section{Methods}

LIVER SAMPLES

For the cytokine mRNA and immunostaining analysis liver tissues were collected from 15 patients with chronic hepatitis C infection (biopsy, $n=12$; resected tissue collected at the time of hepatectomy for liver transplantation, $\mathrm{n}=3$ ). All liver tissues used for cytokine mRNA analysis were stored immediately in liquid nitrogen on collection and no patient had ever been treated with interferon. The control group for cytokine analysis consisted of $\mathrm{HCV}$ negative (anti-HCV antibody negative and reverse transcriptase polymerase chain reaction (RT-PCR) negative) histologically normal liver tissues $(n=6)$ : three were from resected carcinoma (unaffected areas for secondary hepatic malignancy) and the other three were cadaver donors (at the time of hepatectomy). The control groups for immunostaining consisted of group A-three cadaver donor tissues (also used in cytokine estimation); and group B-five randomly selected formalin fixed liver biopsy specimens that were histologically normal by haematoxylin and eosin (H\&E) staining. Note that carcinoma tissues (as used in cytokine analysis) were unavailable for immunostaining.

\section{IMMUNOSTAINING}

A portion of each specimen was fixed in formalin and mounted in paraffin wax. Sections were stained by H\&E and for the expression of the following antigens: CD68 (clone KP1, Dako Corporation, Carpinteria, California, USA) and MAC387 (clone MAC387, Dako Corp.). For CD68 staining, heat induced epitope retrieval (HIER) in Tris-citrate EDTA (pH 8.0) was performed prior to application of the primary antibody. For MAC387 staining enzymatic predigestion with pronase (bacterial protease type XXIV) was used to enhance sensitivity. Following incubation in primary antibodies immunoperoxidase staining was completed using labelled strepavidin-biotin (LSAB kit, Dako Corp.) and diaminobenzidine (DAB) as chromogen.

The density of cells within the portal tract and liver lobule (macrophages/monocytes), which stained positive to the various monoclonal antibodies was determined by counting the number of cells in an area $0.125 \mathrm{~mm}^{2}$ at a magnification of $400 \times$ under a light microscope. Where possible serial sections and mirror sites were used. In each case, for the portal tract and lobular region, at least three fields and 10 fields, respectively, were examined with the mean expressed as cell number per $\mathrm{mm}^{2}$. The cell counting was done in an independent fashion by two of the investigators (PHM and DP) with good correlation: portal CD68 $(r=0.58, \mathrm{p}=0.003)$, lobular CD68 $(r=0.5, \quad \mathrm{p}<0.02)$, portal MAC387 $(r=0.55$, $\mathrm{p}=0.006)$, and lobular MAC387 $(r=0.6$, $\mathrm{p}=0.003$ ). All specimens were histologically assessed by a single pathologist (DP) and graded according to the Scheuer ${ }^{44}$ classification. HCV positive liver tissue was classified as either chronic hepatitis $(n=10)$ or cirrhotic $(n=5)$.

\section{RNA EXTRACTION AND HCV RNA DETECTION BY}

RT-PCR

Liver tissue (approximately 5-10 mg) was homogenised in a liquid nitrogen cooled mortar and pestle; the RNA was extracted as described previously. ${ }^{45}$ The RNA pellet was washed in $75 \%$ ethanol and resuspended in 20 $\mu \mathrm{l}$ of diethylpyrocarbonate (DEPC) treated autoclaved $\mathrm{H}_{2} \mathrm{O}$. The extracted RNA was stored in $1 \mu \mathrm{g}$ aliquots (determined by spectrophotometry at $260 \mathrm{~nm}$ ) in liquid nitrogen. All liver tissues (patient and control) were tested for hepatitis C RNA by nested RT-PCR. ${ }^{7}$

QUANTITATION OF CYTOKINE MRNA BY DOT BLOT PCR

For each sample, a $1 \mu \mathrm{g}$ aliquot of liver RNA was primed with oligo-dT (Boehringer Mannheim, Germany) and reverse transcribed in a $20 \mu$ reaction using Superscript RNase H-enzyme kit (Gibco BRL, Gaithersburg, Maryland, USA) as described previously. ${ }^{23} 4647$ Two separate cDNA syntheses were performed using two different aliquots of RNA from the 
Table 1 Nucleotide sequence of primers

\begin{tabular}{|c|c|c|c|c|}
\hline Name & Polarity & Sequence (5' to 3') & $\begin{array}{l}\text { Predicted size } \\
\text { of product ( } b p)\end{array}$ & Reference \\
\hline \multirow[t]{3}{*}{ IL-1 $\beta$} & Sense & TGAAGCAGCCATGGCAGAAGTACC & \multirow[t]{3}{*}{860} & \multirow[t]{3}{*}{64} \\
\hline & Antisense & AGTCGACATTCAGCACAGGACTCTC & & \\
\hline & Probe & GGTCCTGGAAGGAGCACTTCATC & & \\
\hline \multirow[t]{3}{*}{ IL-6 } & Sense & CAGCTATGAACTCCTTCTCCACAAG & \multirow[t]{3}{*}{655} & \multirow[t]{3}{*}{64} \\
\hline & Antisense & TGCCCATGCTACATTTGCCGAAGAG & & \\
\hline & Probe & ATCCAGTTTGGAAGCATCCAT & & \\
\hline \multirow[t]{3}{*}{ IL-18 } & Sense & GCTTGAATCTAAATTATCAGTC & \multirow[t]{3}{*}{341} & \multirow[t]{3}{*}{65} \\
\hline & Antisense & GAAGATTCAAATTGCATCTTAT & & \\
\hline & Probe & ATGTATAAAGATAGCCAGCC & & \\
\hline \multirow[t]{3}{*}{$\mathrm{TNF} \alpha$} & Sense & GAGCACTGAAAGCATGATCCGGGAC & \multirow[t]{3}{*}{495} & \multirow[t]{3}{*}{47} \\
\hline & Antisense & TTGGTCTGGTAGGAGACGGCGATGC & & \\
\hline & Probe & TGGGCTACAGGCTTGTCACTCG & & \\
\hline \multirow[t]{3}{*}{ MIP1 $\beta$} & Sense & AGCCTCACCTCTGAGAAAACC & \multirow[t]{3}{*}{555} & \\
\hline & Antisense & GCAACAGCAGAGAAACAGTGAC & & \\
\hline & Probe & GCCTGCTGCTTTTCTTACACC & & \\
\hline \multirow[t]{3}{*}{$\mathrm{IFN} \gamma$} & Sense & TCTTTGGCTTAATTCTCTCGGAAACG & \multirow[t]{3}{*}{421} & \multirow[t]{3}{*}{64} \\
\hline & Antisense & GCTTTGCGTTGGACATTCAAGTCAG & & \\
\hline & Probe & CTTGACATTCATGTCTTCCTTGATGG & & \\
\hline \multirow[t]{3}{*}{ Aldolase B } & Sense & GCCTGCACCAAGAAGTATACTCCAG & \multirow[t]{3}{*}{377} & \multirow[t]{3}{*}{64} \\
\hline & Antisense & TAGGTATAGCAGGCTGTGAAGAGCG & & \\
\hline & Probe & TTCCTGCAGCTGTTCCTGGCATCTG & & \\
\hline
\end{tabular}

same test subject. The two separate cDNA products produced were aliquoted and stored in liquid nitrogen until required.

Next, two separate PCR reactions were performed as described previously. ${ }^{23}{ }^{47}$ Briefly, each $50 \mu \mathrm{l}$ reaction contained $2 \mu \mathrm{l}$ cDNA, $0.125 \mathrm{mmol} / 1 \mathrm{dNTP}, 15 \mathrm{pmol}$ forward/reverse primers, $1.5 \mathrm{mmol} / 1 \mathrm{MgCl}_{2}$ (1.25 mmol/1 for $\mathrm{TNF} \alpha$, IL-18), and 1 unit Taq polymerase mixed in $1 \times$ enzyme buffer. After an initial denaturation at $94^{\circ} \mathrm{C}$ all tubes were amplified $\left(94^{\circ} \mathrm{C}, 30\right.$ seconds; $55^{\circ} \mathrm{C}, 30$ seconds; $72^{\circ} \mathrm{C}, 60$ seconds) for either 26 cycles (TNF $\alpha, \operatorname{IFN} \gamma), 24$ cycles (IL-1 $\beta$, IL-6, IL-18, MIP1 $\beta$ ), or 14 cycles (aldolase B). A $4.5 \mu$ l aliquot of PCR product was removed from each tube and transferred to a 96 well plate. Eight aliquots were collected at two cycle intervals. All aliquots were diluted with $100 \mu \mathrm{l}$ of $0.4 \mathrm{M}$ $\mathrm{NaOH}, 10 \mathrm{mM}$ EDTA and blotted onto Hybond $\mathrm{N}^{+}$membrane (Amersham, Buckinghamshire, UK) using a dot blot apparatus (Bio-Rad, Richmond, California, USA). The membranes were hybridised at $42^{\circ} \mathrm{C}$ with an internal probe end labelled with ${ }^{33} \mathrm{P}$ (DNA 5' end labelling kit, Promega, Madison, Wisconsin, USA) in Amersham rapid hyde buffer (Amersham, Buckinghamshire, UK) and washed in $5 \times$ saline sodium citrate (SSC) $/ 0.1 \%$ sodium dodecyl sulphate (SDS) followed by two washes in $1 \times$ SSC $/ 0.1 \%$ SDS. Membranes were exposed on a phosphor imaging plate (Fiji Photo Film Co., Tokyo, Japan) for approximately 1-3 hours, which in turn was scanned on a Fujix Bioimaging analyser, BAS 1000 (Fuji) to quantify the radioactive intensity.

The concentration (molecule number) of cytokine cDNA for each sample was calculated from a standard curve constructed from standards containing a known concentration of cytokine PCR product (DNA molecules) that was included in each PCR run as described previously. ${ }^{23}{ }^{47}$ Note that two separate assays per cytokine were performed; the average of these two assays was used in the analysis. Table 1 displays primer and probe sequences used in this assay.
PCR CONTROLS AND ASSAY VALIDATION In every RNA extraction, cDNA synthesis, and PCR assay, several reactions with only DEPC treated $\mathrm{H}_{2} \mathrm{O}$ were included as a contamination control. In addition, the omission of reverse transcriptase from the cDNA synthesis was included as a negative control for each sample; to control for run to run variation, duplicate PCR and hybridisation reactions were performed for each sample. Contamination prevention measures of Kwok and Higuchi were adhered to at all times. ${ }^{48}$

The dot blot (DB) PCR assay has been validated previously. ${ }^{723}$ In this study, the interassay reproducibility between the separate cDNA/DB-PCR assays was found to be highly significant: aldolase B $(r=0.89, \mathrm{p}<0.0001)$, IFN $\gamma \quad(r=0.91, \mathrm{p}<0.0001), \mathrm{TNF} \alpha \quad(r=0.79$, $\mathrm{p}<0.0001), \operatorname{MIP} 1 \beta(r=0.97, \mathrm{p}<0.0001), \mathrm{IL}-1 \beta$ $(r=0.94, \mathrm{p}<0.0001)$, IL-6 $(r=0.95, \mathrm{p}<0.0001)$, and IL-18 ( $r=0.88, \mathrm{p}<0.0001)$. Secondly, the quality of mRNA extracted from the different liver tissues was compared by measuring aldolase B mRNA expression (internal controlthat is, constitutively expressed by hepatocytes) and the amount measured was similar for all samples $\left(2.2(0.5) \times 10^{6}\right.$ aldolase $\mathrm{B}$ cDNA molecules/ $\mu \mathrm{g}$ total liver RNA, $n=21$ ). No statistical difference was noted in the cytokine mRNA levels between the control carcinoma and cadaver liver tissues; therefore, for statistical analysis they were combined. Finally, negative controls (omitted reverse transcriptase and $\mathrm{H}_{2} \mathrm{O}$ substituted for hepatic cDNA) failed to amplify any product.

\section{STATISTICAL ANALYSIS}

Statistical analysis was performed using Statview version 4.5 software (Abacus Concepts, Berkeley, California, USA). Mean values were compared by the Mann-Whitney test. Individual results were compared by linear regression analysis. Results are expressed as mean (SD) and p values less than 0.05 were considered significant. 


\section{Results}

The age of $\mathrm{HCV}$ positive patients ranged from 32 to 61 years (mean 41.9 years); 10 patients were male and five were female (table 2). No statistical association was found between the patients' demographic details and any of the cytokine or immunostaining results.

EXPRESSION OF CD68 AND MAC387 ANTIGENS CD68 and MAC387 antigens were both expressed in the portal and lobular regions of normal and diseased livers. The anti-CD68 monoclonal highlighted both infiltrating monocytes/ macrophages and resident Kupffer cells in normal and diseased liver tissues. The morphology of cells expressing CD68 antigen appeared to be site specific - the portal tract contained predominantly $\left(\mathrm{CD}^{+} 8^{+}\right)$round/oval shaped cells (presumably infiltrating macrophages/monocytes) while the lobular region contained predominantly $\left(\mathrm{CD} 68^{+}\right)$star shaped or elongated shaped cells (presumably resident Kupffer cells) (see fig 1A, C, E, G). In contrast, the MAC387 antigen positive cells (infiltrating "activated" myelomonocytic cells ${ }^{40}{ }^{42}$ ) were primarily located in the portal region, especially in areas of "interface hepatitis" and were round or oval in shape (see fig $1 \mathrm{D}, \mathrm{F}, \mathrm{H}$ ).

The density of $\mathrm{CD}^{+} 8^{+}$staining cells (fig $2 \mathrm{~A}$ ) within the portal tract was significantly higher in the cohort of $\mathrm{HCV}$ positive livers with chronic hepatitis and/or cirrhosis compared with the normal liver control groups: group A (cadaver donors, $\mathrm{p}=0.008$ ) and group $\mathrm{B}$ (randomly selected normal liver tissues, $\mathrm{p}=0.001)$. A similar pattern was observed for the MAC $387^{+}$cells (HCV versus normal group $\mathrm{A}, \mathrm{p}=0.02$; and normal group $\mathrm{B}, \mathrm{p}=0.001$; fig $2 \mathrm{C})$. These observations contrast with the liver lobule where there was no significant change in $\mathrm{CD} 68^{+}$density between chronic hepatitis, with or without cirrhotic tissue, compared with the normal controls (fig 2B). Finally, the mean density of lobular MAC $387^{+}$stained cells was greater than both the normal control groups, but this difference only reached statistical significance in group B normal liver control $(p=0.006$; fig 2D). Furthermore, there was no significant correlation or trend in either the portal tract or liver lobule between $\mathrm{CD} 68^{+}$or MAC $387^{+}$cell density in $\mathrm{HCV}$ infected tissue, and the total Scheuer score or any of its components.

Finally, it should be noted that: (1) the chronic hepatitis and cirrhotic groups were combined in this analysis as cell numbers were not statistically different between these two groups; (2) we only measured cell density and not total cell population and therefore, at a descriptive level there were obviously more $\mathrm{CD} 8^{+}$and $\mathrm{MAC} 387^{+}$macrophages within the fibrous bands of cirrhotic tissue when compared with chronic hepatitis or normal liver tissue (fig 1).

\section{INTRAHEPATIC CYTOKINE EXPRESSION}

In fig 3, intrahepatic mRNA cytokine levels grouped according to histological classification are compared. The IL-18 mRNA expression was significantly upregulated in HCV associated chronic hepatitis $(p=0.02)$ versus the controls (fig 3C). IL-18 mRNA upregulation was accompanied by a significant increase in IFN $\gamma$ mRNA expression (chronic hepatitis, $p=0.002$; cirrhosis, $p=0.006$; fig 3D). The mRNAs of the three other inflammatory associated cytokines (IL- $1 \beta$, MIP $1 \beta$, and $\mathrm{TNF} \alpha$ ) were also upregulated in $\mathrm{HCV}$ induced chronic hepatitis versus normal controls (fig 3A, B, E); however, only $\mathrm{TNF} \alpha$ reached statistical significance $(p=0.02)$. In contrast, IL-6 mRNA expression was significantly downregulated in chronic hepatitis $(p=0.04)$. In HCV cirrhotic liver tissue, the cytokine mRNAs of all these cytokines were upregulated in relation to the normal controls; however, only IL-1 $\beta$, IL-18, and MIP $1 \beta$ reached statistical significance $(p<0.05$, $\mathrm{p}=0.006, \mathrm{p}<0.05$, respectively). In addition, it was observed that IL- $1 \beta$, IL-6, and MIP1 $\beta$ mRNA upregulation was greater in cirrhotic liver tissue than in chronic hepatitis versus normal controls. Finally, no significant association (by linear regression analysis) was found between any cytokine mRNA level and the total Scheuer score or any of its components (data not shown). The only exception was a weak, but statistically significant negative association between the portal component of the Scheuer score and TNF $\alpha(p=0.04)$.

Table 2 Demographic and histological profile of patients with chronic hepatitis $C$ infection

\begin{tabular}{|c|c|c|c|c|c|c|c|}
\hline Patient & Sex & Age (y) & Histology & $\begin{array}{l}\text { Scheuer } \\
\text { portal score } \\
\text { Total }\end{array}$ & $\begin{array}{l}\text { Scheuer } \\
\text { lobular score } \\
\text { Total }\end{array}$ & $\begin{array}{l}\text { Scheuer } \\
\text { fibrosis score } \\
\text { Total }\end{array}$ & $\begin{array}{l}\text { Scheuer } \\
\text { total score }\end{array}$ \\
\hline 1 & $\mathrm{M}$ & 39 & Chronic hepatitis & 1 & 1 & 0 & 2 \\
\hline 2 & M & 32 & Chronic hepatitis & 2 & 1 & 2 & 5 \\
\hline 3 & $\mathrm{~F}$ & 48 & Chronic hepatitis & 1 & 1 & 2 & 4 \\
\hline 4 & $\mathrm{~F}$ & 35 & Chronic hepatitis & 3 & 1 & 2 & 6 \\
\hline 5 & M & 42 & Chronic hepatitis & 3 & 1 & 2 & 6 \\
\hline 6 & $M$ & 34 & Chronic hepatitis & 2 & 1 & 0 & 3 \\
\hline 7 & M & 38 & Chronic hepatitis & 1 & 1 & 2 & 4 \\
\hline 8 & $M$ & 38 & Chronic hepatitis & 3 & 1 & 2 & 6 \\
\hline 9 & $\mathrm{~F}$ & 37 & Chronic hepatitis & 3 & 2 & 1 & 6 \\
\hline 10 & $M$ & 39 & Chronic hepatitis & 1 & 0 & 1 & 2 \\
\hline 11 & $M$ & 43 & Cirrhosis & 4 & 1 & 4 & 9 \\
\hline 12 & $\mathrm{~F}$ & 58 & Cirrhosis & 4 & 3 & 4 & 11 \\
\hline 13 & M & 51 & Cirrhosis & 4 & 2 & 4 & 10 \\
\hline 14 & $M$ & 34 & Cirrhosis & 4 & 2 & 4 & 10 \\
\hline 15 & $\mathrm{~F}$ & 61 & Cirrhosis & 3 & 0 & 4 & 7 \\
\hline
\end{tabular}

${ }^{\star}$ According to Scheuer. ${ }^{44}$ 
CORRELATIONS BETWEEN CYTOKINES

Relations between different liver cytokine mRNA levels (HCV positive patients only) were investigated by univariant regression analysis. Statistically significant positive correlations were found between IFN $\gamma$ and four of the inflammation associated cytokines (IL-1 $\beta$, IL-18, MIP1 $\beta$, and TNF $\alpha$ ) and between MIP1 $\beta$ and IL-1 $\beta$ (table 3). Interestingly,
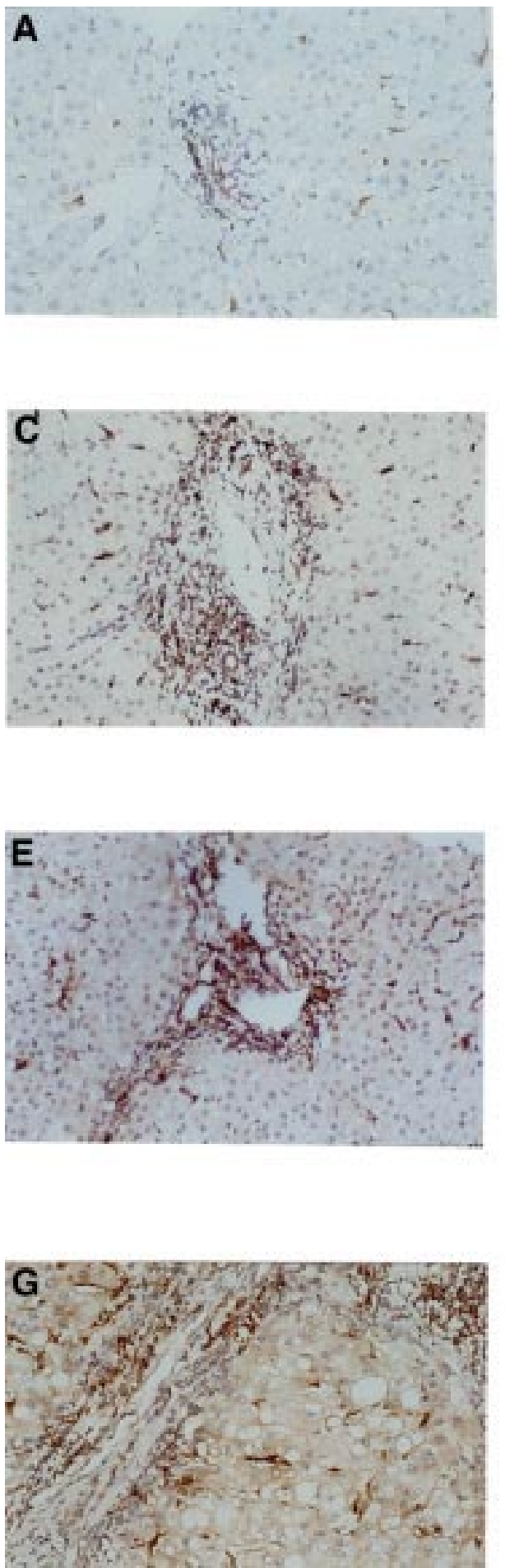

Figure 1 Immunostaining of HCV positive and negative liver tissues with CD68 and MAC387 monoclonal antibodies (original magnification $\times 200$ ). (A) Normal tissue stained with CD68; (B) normal tissue stained with MAC387; (C) chronic hepatitis tissue stained with CD68; (D) chronic hepatitis tissue stained with MAC387; (E) chronic hepatitis tissue stained with CD68; $(F)$ chronic hepatitis tissue stained with MAC387; $(G)$ cirrhotic tissue stained with CD68; $(H)$ cirrhotic tissue stained with MAC387.

TNF $\alpha$ became positively correlated with IL-1 $\beta$ $(\mathrm{p}=0.004, \mathrm{n}=10)$ and MIP1 $\beta \quad(\mathrm{p}=0.0002$, $\mathrm{n}=10$ ) when the cirrhotic patients were removed from the analysis.

\section{CORRELATION BETWEEN CYTOKINE EXPRESSION} AND CD68/MAC387 STAINING

Finally, inflammatory cytokine mRNA levels and CD68 and MAC387 cell densities within
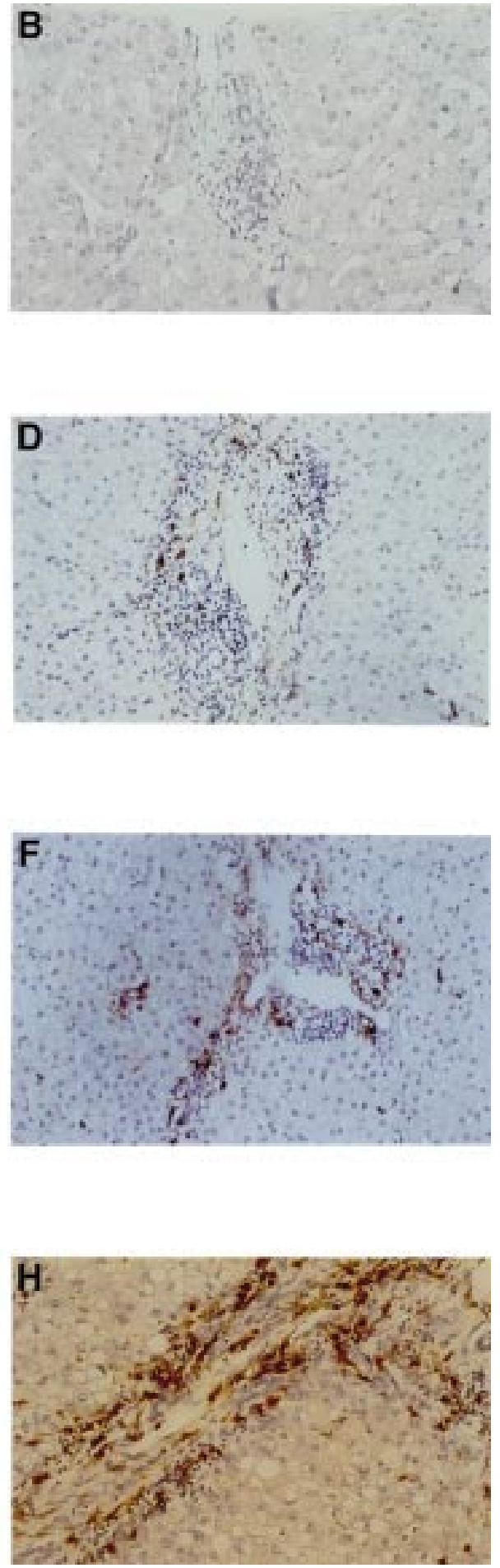
the portal tract and lobular regions of $\mathrm{HCV}$ infected liver tissues were statistically assessed (table 4). Statistically significant positive correlations were found between CD68, MAC387, and IL- $1 \beta$ mRNA ( $p=0.025, p=0.003$, respectively) and MIP $1 \beta$ mRNA $(p=0.009, p=0.01$, respectively). IL-6 mRNA was significantly correlated to the activated macrophage population $\left(\mathrm{MAC} 387^{+}\right)$cell density. Although not significant, TNF $\alpha$ and IFN $\gamma$ mRNAs showed a strong positive association with CD68 cell density ( $p=0.1, p=0.06$, respectively) and likewise IL-18 mRNA with MAC387 cell density $(\mathrm{p}=0.09)$. In contrast, neither lobular CD68 nor MAC387 cell densities were significantly related to any of the cytokines examined.

\section{Discussion}

Although we have previously documented the increased production of intrahepatic Th1 cytokines in chronic $\mathrm{HCV}^{23}$ the role of non-specific inflammatory cells and nonspecific inflammatory cytokines required further investigation. We have addressed this by two separate approaches: (1) measurement of $\mathrm{CD} 68^{+}$and $\mathrm{MAC} 387^{+}$cell densities within the portal tract by immunostaining; and (2) measurement of intrahepatic mRNA from non-specific proinflammatory cytokines.

There are several key findings from this study. Firstly, the non-specific cytokine IL-18 (well characterised IFN $\gamma$ inducing factor ${ }^{49}$ ) and IFN $\gamma$ mRNA expression were significantly correlated with each other and both were significantly upregulated in chronic hepatitis with or without cirrhosis. These data confirmed our earlier finding that IFN $\gamma$ mRNA expression is upregulated in chronic hepatitis $\mathrm{C}^{23}$; likewise, Fukuda et al noted that increased liver injury was significantly associated with increased IFN $\gamma$ mRNA load. ${ }^{50}$ In addition, the strong correlation we observed between the presumed macrophage produced IL-18 mRNA and the presumed $\mathrm{T}$ cell produced IFN $\gamma$ mRNA might suggest that a positive feedback loop exists that is consistent with hepatitis C driving a Th1 type/cell mediated immune response within the liver. The relation between IL-18 and IFN $\gamma$ mRNA has also been detected by Gaweco et al (abstract only) using a non-quantitative PCR method - that is, they found that intrahepatic IL-18 and $\mathrm{IFN} \gamma$
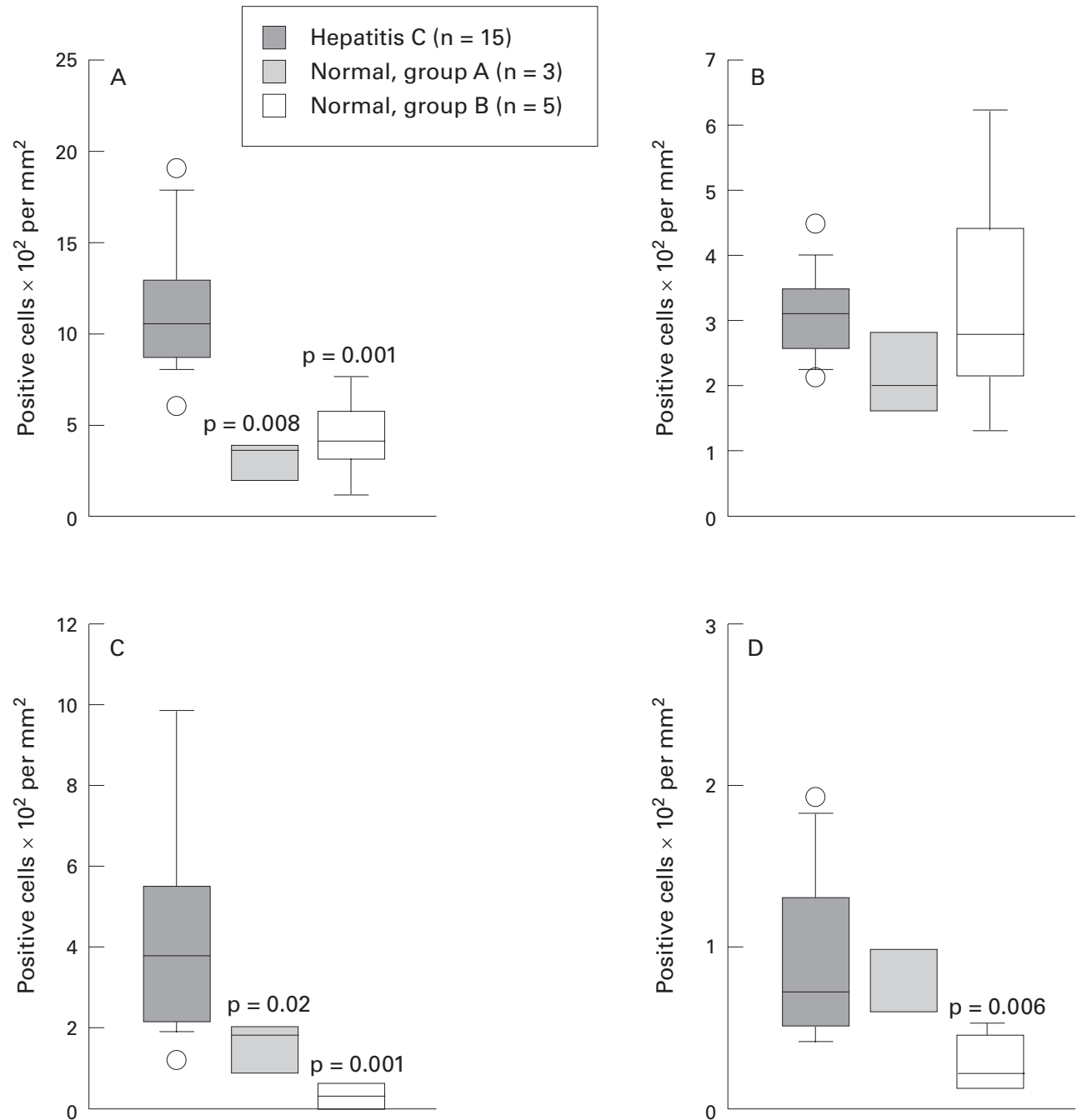

Figure 2 Comparison of $C D 68^{+}$and $M A C 387^{+}$macrophage cell densities. (A) Portal tract CD68 staining; (B) liver lobule CD68 staining; (C) portal tract MAC387 staining; (D) liver lobule MAC387 staining; $p$ values denote the statistical difference between normal liver (groups $A$ or B) versus chronic hepatitis. 


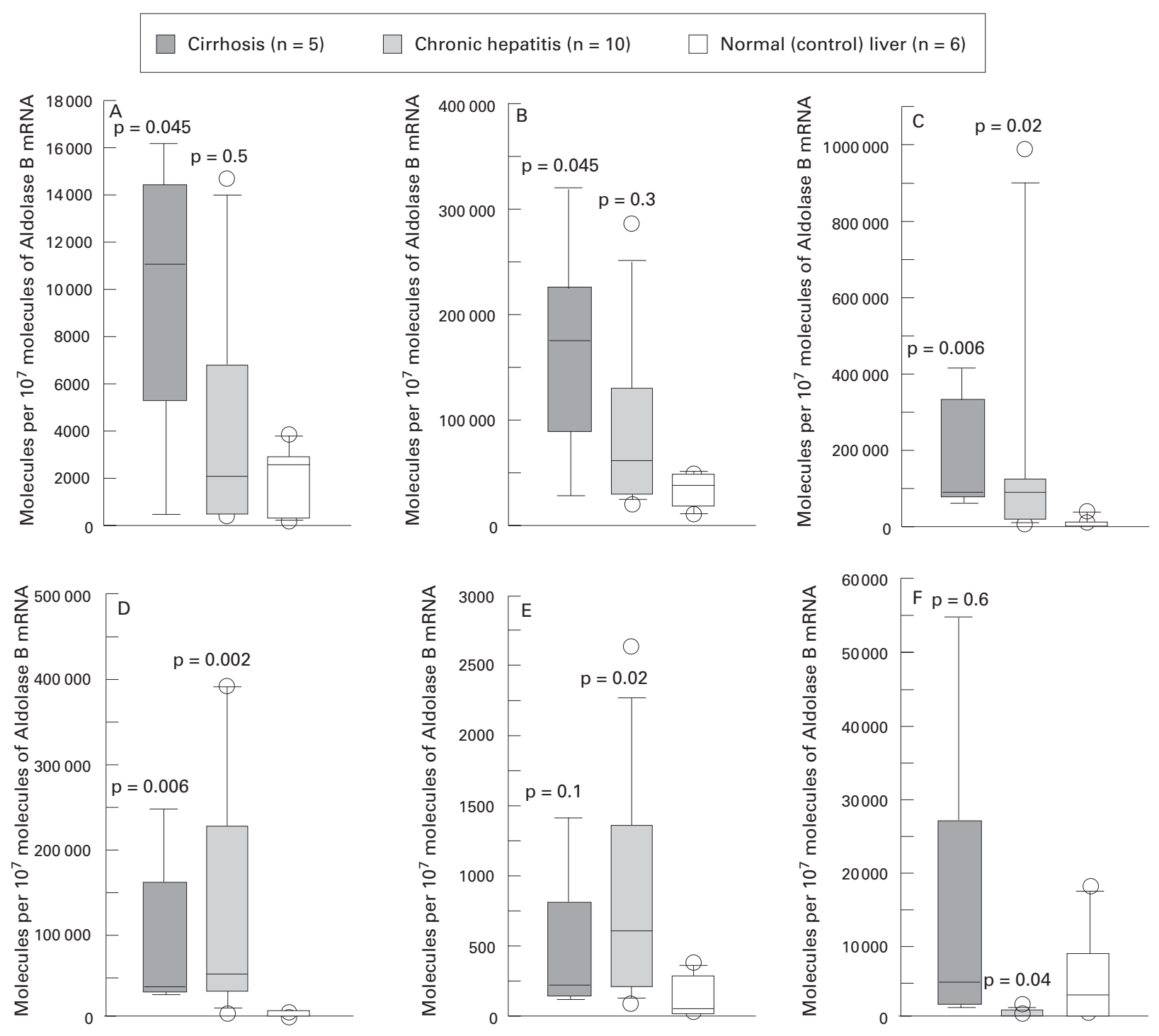

Figure 3 Cytokine expression (molecules per $10^{7}$ molecules of aldolase B) between hepatitis $C$ patients with cirrhosis or chronic hepatitis versus normal controls. (A) IL-1 $\beta$; (B) MIP1 $\beta$; (C) IL-18; (D) IFN $;$; (E) TNFa; (F) IL-6; p values denote the statistical difference between histological groups versus normal controls.

mRNA were both correlated and upregulated in 24 chronic $\mathrm{HCV}$ infected patients, ${ }^{51}$ and they confirmed upregulation of IFN $\gamma$ protein expression by immunostaining. In addition, the positive correlation we found between IFN $\gamma$

Table 3 Comparison of individual cytokines in hepatitis $C$ infected liver by regression analysis $(n=15)$

\begin{tabular}{llllll}
\hline Cytokine & $I L-1 \beta$ & $I L-6$ & $I L-18$ & TNFa & MIP1 $\beta$ \\
\hline IFN $\gamma$ & $\mathrm{p}=0.03$ & $\mathrm{NS}$ & $\mathrm{p}=0.0001$ & $\mathrm{p}=0.009$ & $\mathrm{p}=0.035$ \\
MIP1 $\beta$ & $r=0.56$ & $r=-0.19$ & $r=0.83$ & $r=0.65$ & $r=0.55$ \\
& $\mathrm{p}<0.0001$ & $\mathrm{NS}$ & $\mathrm{NS}$ & $\mathrm{NS}$ & \\
& $r=0.89$ & $r=0.16$ & $r=0.36$ & $r=0.48$ & \\
\hline
\end{tabular}

No significant association was found between IL-6, IL-18, and TNF $\alpha$ and any other cytokine.

Table 4 Comparison of immunostained cell density within the portal tract with cytokine $m R N A$ levels in hepatitis $C$ virus infected liver tissue by regression analysis $(n=15)$

\begin{tabular}{lllllll}
\hline & $I L-1 \beta$ & $I L-6$ & $I L-18$ & $M I P 1 \beta$ & $T N F a$ & $I F N \gamma$ \\
\hline CD68 (portal) & $\mathrm{p}=0.025$ & $\mathrm{NS}$ & $\mathrm{NS}$ & $\mathrm{p}=0.009$ & $\mathrm{NS}$ & $\mathrm{NS}$ \\
& $r=0.57$ & $r=0.24$ & $r=0.13$ & $r=0.65$ & $r=0.43$ & $r=0.49$ \\
MAC387 (portal) & $\mathrm{p}=0.003$ & $\mathrm{p}=0.02$ & $\mathrm{NS}$ & $\mathrm{p}=0.01$ & $\mathrm{NS}$ & $\mathrm{NS}$ \\
& $r=0.72$ & $r=0.58$ & $r=0.44$ & $r=0.64$ & $r=0.01$ & $r=0.43$ \\
\hline
\end{tabular}

No significant association was detected between any cytokine and CD68 or MAC387 cell density within the liver lobule. and other inflammatory cytokines (IL-1 $\beta$, MIP1 $\beta$, and $T N F \alpha$ ) is consistent with a Th1/non-specific cell mediated immune response. Furthermore, support for a Th1 type intrahepatic response comes from the recent identification of CXCR3 expression on all liver infiltrating $\mathrm{T}$ cells in chronic $\mathrm{HCV}^{52}$ The CXCR3 $\alpha$ chemokine receptor is thought to be important in selective recruitment of Th1 type cells to sites of tissue inflammation.

As expected, there was a significant increase in the density of portal tract $\mathrm{CD}^{+} 8^{+}$stained cells in chronic HCV, a phenomenon also observed by Tomita et al. ${ }^{35}$ Intrahepatic CD $68^{+}$ cells in chronic HCV most likely represent cells of the macrophage/Kupffer/monocyte cell lineage, ${ }^{40}$ although CD68 may also be present on other cell types such as neutrophil granulocytes and plasmacytoid T cells. ${ }^{53-55}$ Leicester et al (abstract) used CD14 as a marker for macrophage activation and found that the cell density of activated macrophages in relation to the total macrophage density was increased in HCV chronic hepatitis compared with normal 
tissue controls. ${ }^{33}$ We used the MAC387 antigen as a marker for (a subset of) infiltrating activated macrophages ${ }^{384155}$ and we observed the infiltration of MAC $387^{+}$cells within the portal tracts. However, the number of MAC $387^{+}$cells was significantly less (approximately $45 \%$ of CD68 cell numbers); they were primarily sited at the limiting plate in patients with chronic hepatitis. In this study, we did not detect extensive MAC387 expression by Kupffer cells as previously reported by Flavell et $a l,^{38}$ and our results are therefore consistent with those of other studies. ${ }^{37}{ }^{40-43}$ However, the potential of MAC387 to stain resident Kupffer cells and neutrophil granulocytes ${ }^{38} 43$ may potentially invalidate results, if care is not taken during the cell counting procedure.

The trophism of MAC $387^{+}$cells for the limiting plate is not unique, as cells positive for other potential macrophage markers (CD11b, CD11c, CD14, and CD16) have also been sited primarily at the periphery of HCV positive inflamed portal tracts. ${ }^{30}{ }^{31}$ This trophism may be partially cytokine driven: in a recent study, Narumi and colleagues ${ }^{56}$ found that in $\mathrm{HCV}$ infected liver tissue, IFN inducible protein 10 (IP-10) mRNA ( $\alpha$ chemokine that attracts mononuclear cells and activated $\mathrm{T}$ cells ${ }^{57}$ ) was expressed by hepatocytes specifically in the region around periportal piecemeal necrosis. Furthermore, Shields et al noted increased expression of hepatic IP-10 expression in chronic HCV. ${ }^{52}$ It is unclear, however, whether these attracted periportal mononuclear cells have cytotoxic capabilities or whether they are present in this region as a reaction to the cellular damage, and therefore may play a phagocytic role. Interestingly, MAC $387^{+}$cells also line the outer margin of the portal tract in chronic HBV infection ${ }^{43}$ and like $\mathrm{HCV}$ infection, the exact function of these cells is not clear. However, there are several possible explanations - for example, evidence exists for both antibody dependent monocyte mediated cytotoxicity with neighbouring hepatocytes (periportal) ${ }^{58}$ and for an immunoregulatory role with neighbouring $\mathrm{CD}^{+}$ suppressor/cytotoxic $\mathrm{T}$ cells. ${ }^{43}$

In this study, we are assuming that monoclonal antibodies to CD68 and MAC387 are staining the monocyte/macrophage population within the liver. Ideally, double immunostaining for CD68/MAC387 or if fresh tissue is available, macrophage isolation by collagenase digestion, Percoll density centrifugation followed by immunostaining/in situ hybridisation/ RT-PCR, would not only allow more specific association of these markers to the macrophage population, but would also facilitate cytokine characterisation within this group. Unfortunately, in this study, these methods were unable to be performed and therefore, our results relating their expression to specific locations/ cell types and to each other are limited.

In addition to IL-18, a wide range of other non-specific proinflammatory associated intrahepatic cytokines were examined. These cytokines may be produced by many cell types: for example, IL-1 $\beta$ by fibroblasts and epithelial cells $^{59}$; TNF $\alpha$ by neutrophils, $\mathrm{T}$ cells, and NK cells ${ }^{60}$; and MIP1 $\beta$ by $\mathrm{T}$ cells, B cells, fibroblasts, and endothelial cells. ${ }^{61}$ However, the observed upregulation of these cytokines (except IL-6) in HCV infected liver tissue is consistent with macrophage activation. Furthermore, the levels of increase were marginal compared with the very significant levels of IL-18 and IFN $\gamma$ - for example, only $\mathrm{TNF} \alpha$ mRNA was significantly increased in noncirrhotic HCV, but we have noted that these marginal increases maybe influenced by our controls. Specifically, histological examination of our control liver tissues revealed low level inflammation within the portal tracts, a probable consequence of being taken from cadaver donors (inadvertent macrophage activation during ischaemia and organ preservation). Consequently, some cytokine levels within these controls may be marginally upregulated and this may mask the true difference in cytokine expression between $\mathrm{HCV}$ infected and uninfected "normal" liver.

The monokine IL-6 warrants a special mention, because it was the only cytokine mRNA to be significantly downregulated in chronic hepatitis without cirrhosis; a similar observation was reported by Gaweco et al. ${ }^{26}$ Fukuda et al also observed that IL- 6 mRNA expression was inversely proportional to the severity of liver injury. ${ }^{50}$ Additional indirect support for HCV associated intrahepatic IL-6 downregulation was the detection of $\mathrm{C}$ reactive protein (IL-6 upregulates its production) downregulation in chronic HCV liver injury. ${ }^{62}$ However, IL-6 downregulation in chronic hepatitis may only reflect a Th1 dominated intrahepatic microenviroment - that is, IL-6 maybe naturally suppressed because it is functionally antiinflammatory and associated with Th2 cell activity; alternatively, HCV may directly effect IL-6 mRNA expression. Further investigation is required to address these issues - for example, the observed upregulation of IL- 6 mRNA in cirrhosis may be due to its production by activated hepatic stellate cells in addition to other IL-6 sources such as Kupffer, mononuclear, Th2, and endothelial cells. ${ }^{63}$

Finally, two important associations were found between cytokine mRNA expression, and CD68 and MAC387 cell density within the portal tract. Firstly, a statistically significant association was found between $\mathrm{MAC} 387^{+}$cell density and the cytokines IL- $1 \beta$, MIP $1 \beta$, and IL-6. Secondly, a positive association (not significant) was noted between $\mathrm{MAC} 387^{+}$cell density and cytokines IL-18 $(\mathrm{p}=0.09)$ and IFN $\gamma(p=0.1)$. To understand these observations better - that is, to clarify the exact role of intrahepatic macrophages in chronic HCV, requires the direct identification of the cellular sources of these cytokines. For example, the observed upregulation of intrahepatic cytokines may be due to an increase in the number of macrophages attracted to the liver (possibly IL-1 $\beta$ and MIP1 $\beta$ ) and/or it may be due to an increase in the activation state of a subpopulation of intrahepatic macrophages (possibly IL-18). To explore this issue further, future studies could include in situ hybridisation and/or cellular isolation and FACS analy- 
sis for macrophage markers in addition to cytokine estimation.

To conclude, this study showed a close association between IL-18 and IFN $\gamma$ mRNA production, which suggests that the intrahepatic immune response involves a partnership between macrophages and Th type 1 cells. In addition, intrahepatic cytokine mRNA production varied greatly from a notable upregulation in IL-18, to a strong increase in $\mathrm{TNF} \alpha$, to a weak upregulation in IL- $1 \beta$ and MIP1 $\beta$, and to a downregulation in IL-6. Furthermore, some cytokine mRNA levels (MIP1 $\beta$ and IL-1 $\beta$ ) correlated with $\mathrm{MAC} 87^{+}$and $\mathrm{CD}^{+} 8^{+}$cell densities within the portal tracts. Finally, we showed a significant increase in intrahepatic macrophage numbers in persistent $\mathrm{HCV}$ infection. In summary, these data further support the persistent intrahepatic cell mediated immune response model in chronic HCV, but do not explain why HCV persists in the presence of this response.

The authors wish to acknowledge Ms Robyne Soper from the Anatomical Pathology Department, for her assistance in the preparation of paraffin wax sections for immunostaining; and Drs Alex Bishop and Mark Gorrell for their helpful discussions.

1 Alter MJ, Margolis HS, Krawczynski K, et al. The natural history of community-acquired hepatitis $\mathrm{C}$ in the United
States. The Sentinel Counties Chronic non-A, non-B States. The Sentinel Counties Chronic non-A, non-B
Hepatitis Study Team. N Engl f Med 1992;327:1899-905.

2 Di Bisceglie AM, Goodman ZD, Ishak KG, et al. Long-term clinical and histopathological follow-up of chronic postclinical and histopathological follow-up of chro
transfusion hepatitis. Hepatology 1991;14:969-74.

3 Seeff LB. Natural history of viral hepatitis, type C. Semin Seeff LB. Natural history of
Gastrointest Dis 1995;6:20-7.

4 Simmonds P, Holmes EC, Cha TA, et al. Classification of hepatitis $C$ virus into six major genotypes and a series of subtypes by phylogenetic analysis of the NS-5 region. $\mathcal{F}$ Gen Virol 1993;74:2391-9

5 Bukh J, Miller RH, Purcell RH. Genetic heterogeneity of hepatitis C virus: quasispecies and genotypes. Semin Liver Dis 1995;15:41-63.

6 Mita E, Hayashi N, Kanazawa Y, et al. Hepatitis C virus genotype and RNA titer in the progression of type C chronic liver disease. F Hepatol 1994;21:468-73.

7 McGuinness PH, Bishop GA, Painter DM, et al. Intrahepatic hepatitis C RNA levels do not correlate with degree of liver injury in patients with chronic hepatitis C. Hepatology 1996;23:676-87.

8 Nakagawa H, Shimomura H, Hasui T, et al. Quantitative detection of hepatitis $\mathrm{C}$ virus genome in liver tissue and circulation by competitive reverse transcriptioncirculation by competitive reverse transcription-
polymerase chain reaction. Dig Dis Sci 1994;39:225-33.

polymerase chain reaction. Dig Dis Sci 1994;39:225-33.
9 Sakamoto N, Enomoto N, Kurosaki M, et al. Detection and quantification of hepatitis $\mathrm{C}$ virus RNA replication in the quantification of hepatitis C vi
liver. F Hepatol 1994;20:593-7.

10 Martell M, Esteban JI, Quer J, et al. Hepatitis C virus (HCV) circulates as a population of different but closely related genomes: quasispecies nature of $\mathrm{HCV}$ genome distribution. F Virol 1992;66:3225-9.

11 Koizumi K, Enomoto N, Kurosaki M, et al. Diversity of quasispecies in various disease stages of chronic hepatitis $C$ virus infection and its significance in interferon treatment. Hepatology 1995;22:30-5.

12 Zeuzem S, Schmidt JM, Lee JH, et al. Effect of interferon alfa on the dynamics of hepatitis $\mathrm{C}$ virus turnover in vivo. Hepatology 1996;23:366-71.

13 Cooper S, Kowalski H, Erickson AL, et al. The presentation of a hepatitis $\mathrm{C}$ viral peptide by distinct major histocompatibility complex class 1 allotypes from two chimpanzee speibility complex class 1 allotypes fron
cies. F Exp Med 1996;183:663-8.

14 Pasi KJ, Evans JA, Wadhwa M, et al. Association of changes in monocyte antigen presentation and cytokine production in haemophilic boys with treatment and blood-borne virus infection. Br f Haematol 1995;91:191-6.

15 Bertoletti A, Delios MM, Boni C, et al. Different cytokine profiles of intrahepatic T cells in chronic hepatitis B and hepatitis C virus infections. Gastroenterology 1997;112: 193-9.

16 Dumoulin FL, Bach A, Leifeld L, et al. Semiquantitative analysis of intrahepatic cytokine $\mathrm{mRNAs}$ in chronic hepatitis C. F Infect Dis 1997;175:681-5.

17 Koziel MJ. The role of immune responses in the pathogenesis of hepatitis C virus infection. $\mathcal{F}$ Viral Hepat 1997;4:3141 .

18 Simmonds P, Rose KA, Graham S, et al. Mapping of serotype-specific, immunodominant epitopes in the NS- 4 region of hepatitis $\mathrm{C}$ virus (HCV): use of type-specific peptypes 1, 2, and 3. F Clin Microbiol 1993;31:1493-503.
19 Gabrielli A, Zhang ZX, Cherubini G, et al. Differential humoral immune response against hepatitis $C$ virus antigenic synthetic peptides in infected patients with and without mixed cryoglobulinaemia. Clin Exp Immunol 1996; 105:59-64.

20 Bansal AS, Bruce J, Hogan PG, et al. Serum soluble CD23 but not IL18, IL10, GM-CSF, or IFN-gamma is elevated in patients with hepatitis $\mathrm{C}$ infection. Clin Immunol Immunopathol 1997;84:139-44.

21 Minutello MA, Pileri P, Unutmaz D, et al. Compartmentalization of T lymphocytes to the site of disease: intrahepatic CD4+ T cells specific for the protein NS4 of hepatitis C virus in patients with chronic hepatitis C. f Exp Med 1993; 178:17-25.

22 Spengler U, Lechmann $M$, Irrgang $\mathrm{B}$, et al. Immune responses in hepatitis C virus infection. f Hepatol 1996;24: $20-5$.

23 Napoli J, Bishop GA, McGuinness PH, et al. Progressive liver injury in chronic hepatitis $\mathrm{C}$ infection correlates with increased intrahepatic expression of Th1-associated cytokines. Hepatology 1996;24:759-65.

24 McCaughan GW, Napoli J, McGuinness P, et al. T1 vs T2 cytokine responses in chronic HCV: implications for mechanisms of liver injury. Viral Hepatitis Reviews 1997;3: $129-42$

25 Khakoo SI, Soni PN, Savage K, et al. Lymphocyte and macrophage phenotypes in chronic hepatitis C infection. Correlation with disease activity. Am f Pathol 1997;150: 963-70.

26 Gaweco AS, Rustgi V, Hassanein T, et al. Defective antiviral cytokines in chronic hepatitis $\mathrm{C}$ virus infected livers [abstract]. Hepatology 1995;22:335A.

27 Dumoulin FL, Honecker T, Sauerbruch T, et al. Decreased intrahepatic IL-1 $\beta$ and TNF $\alpha$ mRNA levels in chronic hepatitis C: clues to impaired function of mononuclear phagocyte system in chronic hepatitis C [abstract]. IX Triennial International Symposium on Viral Hepatitis and Liver Disease, Rome, 1996:174A.

28 Marrogi AJ, Cheles MK, Gerber MA. Chronic hepatitis C. Analysis of host immune response by immunochemistry. Arch Pathol Lab Med 1995;119:232-7.

29 Gonzalez-Amaro R, Garcia-Monzon C, Garcia-Buey L, et al. Induction of tumor necrosis factor alpha production by human hepatocytes in chronic viral hepatitis. 7 Exp Med 1994;179:841-8.

30 Garcia-Monzon C, Garcia-Bluey L, Borque MJ, et al. Phenotypic and functional characterization of intrahepatic natural killer and macrophages in viral chronic hepatitis $\mathrm{C}$ (VCH) [abstract]. Hepatology 1995;22:337A

31 Garcia-Monzon C, Garcia-Iglesias C, Garcia-Bluey L, et al. Phenotypic and functional characterisation of intrahepatic natural killer cells and macrophages in viral chronic hepatitis [abstract]. International Meeting on Hepatitis C Virus and Related Viruses: Molecular Virology and Pathogenesis, Venenzia-Lido, Italy, 1998:P232.

32 Yamamoto $\mathrm{K}$, Ohmoto M, Matsumoto S, et al. Activated liver macrophages in human liver diseases. $f$ Gastroenterol Hepatol 1995;10:S72-6.

33 Leicester KL, Olynyk JK, Fox ES, et al. CD14-positive macrophages/monocytes in hepatitis $\mathrm{C}$ injury [abstract]. $\mathcal{F}$ Gastroenterol Hepatol 1997;12(suppl):A30.

34 Rutherford MS, Witsell A, Schook LB. Mechanisms generating functionally heterogenous macrophages: chaos revisted. F Leukoc Biol 1993;53:602-18

35 Tomita M, Yamamoto K, Kobashi H, et al. Immunohistochemical phenotyping of liver macrophages in normal and diseased human liver. Hepatology 1994;20:317-25.

36 Tomita $\mathrm{M}$, Yamamoto $\mathrm{K}$, Kobashi $\mathrm{H}$, et al. Immunohistochemical analysis on the expressions of maturation associated antigens, Fc-gamma receptors and CD14 in normal and diseased human liver macrophages. International Hepatology Communications 1994;2:245-9.

37 Davey FR, Gatter KC, Ralfkiaer E, et al. Immunophenotyping of non-Hodgkin's lymphomas using a panel of antibodies on paraffin-embedded tissues. Am $\mathcal{F}$ Pathol 1987;129: 54-63.

38 Flavell DJ, Jones DB, Wright DH. Identification of tissue histocytes on paraffin sections by a new monoclonal antibody. F Histochem Cytochem 1987;35:1217-26.

39 Brandtzaeg P, Jones DB, Flavell DJ, et al. MAC387 antibody and detection of formalin resistant myelomonocytic L1 antigen. F Clin Pathol 1988;41:963-70.

40 Pulford KAF, Rigney EM, Micklem KJ, et al. KP1: a new monoclonal antibody that detects a monocyte/macrophage associated antigen in routinely processed tissue sections. $\mathcal{F}$ Clin Pathol 1989;42:414-21.

41 Brandtzaeg P, Dale I, Fagerhol MK. Distribution of a formalin-resistant myelomonocytic antigen (L1) in human tissues. I. Comparison with other leukocyte markers by paired immunofluorescence and immunoenzyme staining. Am $\mathcal{F}$ Clin Pathol 1987;87:681-99.

42 Bardadin KA, Scheuer PJ, Peczek A, et al. Immunocytochemical observations on macrophage populations in normal fetal and adult human liver. F Pathol 1991;164:253-9.

43 van den Oord JJ, De Vos R, Facchetti F, et al. Distribution of non-lymphoid, inflammatory cells in chronic HBV infection. $\mathcal{F}$ Pathol 1990;160:223-30.

44 Scheuer PJ. Classification of chronic viral hepatitis: a need for reassessment. F Hepatol 1991;13:372-4.

45 Chomczynski P, Sacchi N. Single step method of RNA isolation by acid guanidinium thiocyanate-phenol-chloroform extraction. Ann Biochem 1987;162:156-8. 
46 McGuinness PH, Bishop GA, Lien A, et al. Detection of serum hepatitis C virus RNA in HCV antibodyserum hepatitis $\mathrm{C}$ virus RNA in HCV antibody-
seropositive volunteer blood donors. Hepatology 1993;18: 485-90.

47 Bishop GA, Rokahr KL, Lowes M, et al. Quantitative reverse transcriptase-PCR amplification of cytokine mRNA in liver biopsy specimens using a non-competitive method. Immunol Cell Biol 1997;75:142-7.

48 Kwok S, Higuchi R. Avoiding false positives with PCR. Nature 1989;339:237-8.

49 Takeda K, Tsutsui H, Yoshimoto T, et al. Defective NK cell activity and Thl response in IL-18-deficient mice. Immunity 1998;8:383-90.

50 Fukuda R, Ishimura N, Ishihara S, et al. Intrahepatic expression of pro-inflammatory cytokine mRNAs and interferon efficacy in chronic hepatitis C. Liver 1996;16: 390-9.

51 Gaweco AS, Rustgi VK, Mitchell B, et al. Concordant type 1 cytokine mRNA and protein expression in chronic HCVinfected livers is associated with the transcription of the novel IFN- $\gamma$ inducing factor (IL-18) gene [abstract]. Hepatology 1997;26:409A.

52 Shields PL, Salmon M, Hubscher SG, et al. Chemokinechemokine receptor interactions provide a mechanism for the selective recruitment of Th1 lymphocytes into hepatitis $\mathrm{C}$ infected liver [abstract]. Hepatology 1998;28:465A

53 Ruco LP, Pulford KA, Mason DY, et al. Expression of macrophage-associated antigens in tissues involved by Langerhans cell histiocytosis (histiocytosis X). Am $\mathcal{F}$ Clin Pathol 1989;92:273-9.

54 Warnke R, Pulford K, Pallesen G, et al. Diagnosis of myelomonocytic and macrophage neoplasms in routinely processed tissue biopsies with monoclonal antibody KP1. Am Pathol 1989;135:1089-95.

55 Brandtzaeg P, Dale I, Gabrielsen TO. The leucocyte protein L1 (calprotectin): usefulness as an immunohistochemical marker and putative biological function. Histopathology 1992;21:191-6.
56 Narumi S, Tominaga Y, Tamaru $M$, et al. Expression of IFN-inducible protein-10 in chronic hepatitis. F Immunol 1997; 158:5536-44.

57 Taub DD, Lloyd AR, Conlon K, et al. Recombinant human interferon-inducible protein 10 is a chemoattractant for human monocytes and $\mathrm{T}$ lymphocytes and promotes $\mathrm{T}$ cell adhesion to endothelial cells. F Exp Med 1993;177:1809-14.

58 Bernuau D, Rogier E, Feldmann G. A quantitative ultrastructural analysis of the leukocytes in contact with hepatocytes in chronic active hepatitis, with a cytochemical detection of mononuclear phagocytes. Am $f$ Pathol 1982;109:310-20.

59 Dinarello CA. Interleukin 1 and interleukin 1 antagonism. Blood 1991;77:1627-52.

60 Vilcek J, Lee TH. Tumor necrosis factor. New insights into the molecular mechanisms of its multiple actions. F Biol Chem 1991;266:7313-16.

61 Miller MD, Krangel MS. Biology and biochemistry of the chemokines: a family of chemotactic and inflammatory cytokines. Crit Rev Immunol 1992;12:17-46.

62 Tarocco RP, Fenoglio LM, Falbo V, et al. IL-6 receptor expression on hepatocytes in HCV infection [abstract]. Gastroenterology 1997;112:A1397.

63 Hellerbrand C, Jobin C, Iimuro Y, et al. Inhibition of NFkappaB in activated rat hepatic stellate cells by proteasome inhibitors and an IkappaB super-repressor. Hepatology 1998;27:1285-95.

64 Bishop G, Rokahr K, Napoli J, et al. Intragraft cytokine mRNA levels in human allograft rejection analysed by the reverse transcription and semiquantitative polymerase chain reaction (PCR) amplification. Transplant Immunol 1993;1:253-61.

65 Ushio S, Namba M, Okura T, et al. Cloning of the cDNA for human IFN-gamma-inducing factor, expression in Escherichia coli, and studies on the biologic activities of the protein. F Immunol 1996;156:4274-9. 